\title{
Enighed om målet, men strid om midlerne
}

\section{Helen Krag}

\section{Rapport fra en dansk observatør ved organisatio- nen Frit Kaukasus, der har brudt med eksilleder Akhmed Sakajev}

Som følge af Ruslands militære indgriben i Tjetjenien blev situationen i Nordkaukasus ikke blot radikaliseret men også regionaliseret. Den af Putin indsatte tjetjenske præsident Ramsan Kadyrov styrer Tjetjenien som et autoritært terrorregime, mens terrorprægede modstandsaktiviteter har spredt sig til naborepublikkerne Dagestan, Ingusjetien og Kabardinien-Balkarien.

Parallelt hermed er resterne af den tjetjenske uafhængighedshær blevet omdannet til en kampenhed for et kaukasisk emirat under 'Amir' Doku Umarov, hvori Tjetjenien kun indgår som provins eller villayat. I praksis betyder det nordkaukasiske emirat nedlæggelse af Republikken Itjkerija, som kampen mod Rusland handlede om.

Doku Umarovs Emirat er blot den ene side af regionaliseringen, det vil sige en spredning af konflikten i
Tjetjenien til hele den nordlige Kaukasusregion. En anden udvikling sker for tiden i eksil. Tjetjenernes kamp for uafhængighed udkæmpes i dag under vanskelige vilkår i udlandet. Vanskelighederne skyldes dels, at alle eksilpolitikere er relativt isolerede og som flygtninge og asylansøgere spredt over mange lande, og dels, at deres politiske legitimitet med årene er falmet i hjemlandet, fordi kontakten fra eksil til hjemlandet er vanskelig.

I modsætning til den radikale udvikling i Kaukasus er udviklingen i eksilet moderat og nærmest demokratisk. Den bedst kendte eksilpolitiker er med sikkerhed ministerpræsidenten i den tidligere de facto uafhængige Tjetjenske Republik Itjkeria (TjRI) Akhmed Sakajev, hvis position skildres andetsteds i dette nummer af Udenrigs.

Men også i eksilet har der ved si- 
den af den nationale frihedsbevægelse dannet sig en bevægelse, som fokuserer på hele Kaukasusregionen. Det er bevægelsen 'Frit Kaukasus - for Fred, Uafhængighed og Demokrati i Kaukasus'. Den blev grundlagt i februar 2009 i Danmark, nærmere betegnet i Herlev.

Baggrunden er følgende: i begyndelsen af 2009 blev det kendt, at Akhmed Sakajevs eksilregering ønskede at forhandle med ledelsen af den Russiske Føderation. Dette skete ifølge Akhmed Sakajev selv af pragmatiske grunde, fordi man indså, at det er umuligt at vinde en krig mod det store Rusland.

Målet for modstandskampen var og er størst mulig uafhængighed under et demokratisk styre, og det mente Sakajev var muligt gennem forhandlinger med Rusland.

Det førte til uoverensstemmelser i eksilregeringen, og nogle ministre meldte sig ud i desperation. De ville ikke under nogen omstændigheder gå på kompromis med Rusland, som de har kæmpet imod i så mange år. De ville ikke tale eller samarbejde med den tidligere fjende, som har forvoldt så meget lidelse. I denne gruppe af forhandlingsmodstandere vandt således idealismen over pragmatikken.

Gruppen vil arbejde på en alternativ fremtidsplan. Dens politiske mål er total uafhængighed fra Rusland. Fokus for den nye bevægelses arbejde er hele Kaukasus.

I august 2009 blev det meddelt, at
Sakajev førte 'konsultationer' med formanden for Kadyrov-regeringens såkaldte parlament, Duvakha Abdurakhmanov. Angiveligt blev der tilbudt et samarbejde omkring en slags uafhængighed for Tjetjenien svarende til Abkhasiens og Sydossetiens, efter at disse to republikker var blevet indlemmet i den Russiske Føderation som følge af Ruslands krig i Georgien i august 2009. Samtalerne skulle efter sigende også indebære, at Akhmed Sakajev skulle vende tilbage til Tjetjenien.

Sommeren 2009 var derefter præget af mange rygter. Dels rygter om, at konsultationerne var initieret af Ramsan Kadyrov, dels af Vladimir Putin i Moskva.

\section{Sakajev afsat per dekret}

Derudover gik der en del rygter om, hvad et politisk kompromis præcist skulle indeholde. En af følgerne af samtaler og rygter blev, at formanden for parlamentet for den Tjetjenske Republik Itjkerija, Zhalaudi Saraljapov, udstedte et dekret, hvori han 'afsatte' Sakajevs regering. En anden følge blev, at Umarov den 25. august 2009 udstedte en fatwa mod Sakajev. Kadyrov kaldte Sakajev en 'løgner' og Abdurakhmanov kaldte ham en 'forræder', fordi Sakajev ikke vil vende tilbage til Tjetjenien, uden at uafhængigheden er garanteret. (RFE/ RL 3.11.09). Sakajev er efter denne kontrovers dog stadigvæk den ubestridte leder af den tje- 
tjenske eksilregering, men han kunne ikke forhindre splittelsen i eksilbevægelsen.

Førende skikkelser i eksilbevægelsen 'Frit Kaukasus' er den tidligere tjetjenske eksilminister for information og kommunikation, Iljas Musajev, og Grosnijs tidligere kommandant, Isa Munajev, som begge bor i København. Sakajevs ændrede holdning til Kadyrovs rolle var helt uacceptabel for de to. (Mairbek Vatchagaev: The Jamestown Foundation, North Caucasus Weekly Volume: 10 Issue: 5//February 6, 2009). Det menes, at Munajev stadig nyder respekt i Tjetjenien.

Det karakteristiske for bevægelsen er, at den vil samarbejde med det øvrige Kaukasus, især Georgien, som efter den tabte krig mod Rusland gerne støtter den tjetjenske sag, og især ønsker uafhængighed for hele regionen. Derudover indgår ingusjetere og aserbajdsjanere og flere andre i bevægelsens arbejde. Også denne bevægelse ønsker en demokratisk udvikling. Religionen spiller ingen rolle i bevægelsen, bl.a. fordi de samarbejder med ikke-muslimske folk i eksil. Det er de nødt til, fordi de alene er for svage. "Russerne har ydmyget os alle. Vi skal forene os og sammen slås for friheden" er et ofte gentaget udsagn.

\section{Fælles kaukasisk identitet}

Jeg har været inviteret til at deltage i bevægelsens møder i København
(Herlev) som observatør og ekspert for Nordkaukasus, fordi jeg har skrevet om Nordkaukasus og fordi jeg for tiden er involveret i et projekt om nordkaukasisk eksil (finansieret af det Strategiske Forskningsråd). Ud over mig er også en af lederne af den danske Tjetjenien-Komité inviteret til møderne. Første møde fandt sted 8. februar 2009. Isa Munajev (Tjetjenien) blev valgt som foreningens formand. Rusudan Giorgberidze (Georgien) og Safar Sadigi (Aserbajdsjan) som næstformænd.

Det første møde dannede præcedens for mange efterfølgende $m \varnothing$ der, som alle foregår i stor alvor. Mødet begyndte ved at flere flag blev anbragt på væggen: det tjetjenske, det georgiske, det aserbejdsjanske og det danske flag. Det var vigtigt, at deltagerne kunne fotograferes foran flagene, og billederne lægges ud på nettet. Man drøftede foreningens navn og vedtægter. I referatet fra mødet blev det anført, at konferencen - som mødet blev kaldt - var "afholdelse af en ny social-politisk bevægelse, som ville forene kaukasiske folk i kampen mod russisk politik i Kaukasus". Omgangsformen var formel venlig. Der deltog også unge mennesker, som viste den allerstørste respekt for de ældre deltagere.

Mange formaliteter indgik i diskussionerne: om et logo for eksempel, som skulle vise eller konstruere en fælles kaukasisk identitet. Her 
kom de første uenigheder frem i lyset. Logoet skulle vise de kaukasiske bjerge og et af de karakteristiske kaukasiske tårne. Jeg nævner dette, fordi der allerede her blev tydeligt, hvor meget der skal diskuteres og findes kompromiser om, hvis man vil et fælles kaukasisk projekt. Bjerge og tårne ser forskellige ud afhængigt af, om de ses sydfra eller nordfra, tæt på eller langt fra. Man drøftede en hjemmeside. Også her viste det sig, at der var uenigheder om holdninger og tekster. Hvad er for eksempel vigtigst: folk eller lande?

Også politiske diskussioner tog fart: nogle medlemmer af det georgiske og det aserbajdsjanske eksil arbejder sammen med deres regeringer, andre er flygtet, fordi de er regeringens fjender. Det giver forskellige muligheder for støtte og samarbejde. Et af de vanskeligste spørgsmål dukkede op ved flere møder: Hvad gør man, hvis nogle af de grupper, som man har været i krig med, ønsker medlemskab i bevægelsen? Hvordan skal en aserbajdsjaner forholde sig, hvis en armenier dukker op? Eller en georgier, når en abkhasier ønsker medlemskab? Eller en ingusjeter, når en osseter kommer? Der er konflikter nok, som kunne splitte foreningen.

Som observatør ved møderne må jeg anerkendende konstatere, at der altid var mødedeltagere, som kunne skære igennem og kalde til fornuft: alle som ønsker frihed for Kaukasus må kunne være med og så må man diskutere sine uenigheder i en demokratisk form. Det viste mig, at eksilet i Vesteuropa har haft sin integrative kraft: Diskussionen blev sat i højsædet i stedet for krigene, som de har fundet sted i Kaukasus. At holde sammen er den sidste mulighed for hen ad vejen at opnå en form for uafhængighed. Men uden skænderier og uden vrede går det ikke. Ingen af de deltagende staters integritet står i sidste ende til diskussion, og det gør et fælles kaukasisk standpunkt til en stor udfordring, der lejlighedsvis kan ligne diskussionerne om Israel og Palæstina.

\section{Et demokratisk Kaukasus muligt?}

Det blev meget hurtigt besluttet at afholde en konference under overskriften 'Kan der være et frit og demokratisk Kaukasus?'. Også her viste diskussionerne sig at være fornuftige. Problemet er - som for de fleste foreninger i Danmark - at de ikke har penge, og at mennesker i eksil ikke har erfaring med at søge diverse fonde. Konferencen i april 2009 blev et eksperiment eller mere korrekt en forberedelse til en større konference for at samle den kaukasiske diaspora, som det dog trods mange forsøg ikke lykkedes at skaffe penge til.

Til gengæld blev foreningen inviteret til en diasporakonference i Tbilisi i Georgien. Det er tydeligt, at Georgien som stat er en vigtig medspiller. Det var også tydeligt, at der 
er en slags konkurrence mellem Frit Kaukasus, hvor tjetjenere er ledende, og den tjetjenske eksilregering. For eksempel planlagde de to eksilorganisationer på et tidspunkt at afholde konferencer på en og samme dag.

Eksilregeringen ønsker en samlet eksilbevægelsen og ser gerne alle grupperinger deltage i deres konferencer, mens bevægelsen Frit Kaukasus er meget mere forbeholden.

Som tjetjenerne siger det, så kan det ødelægge ens anseelse i såvel eksilet som i hjemlandet, hvis man støtter den forkerte bevægelse eller forkerte personer.

Mine forsøg på at overtale dem til at tale med den anden eksilbevægelse afvises konsekvent og betegnes som dansk mentalitet. Det anerkendes, at alle i sidste ende vil det samme, nemlig et frit Tjetjenien, men at de vil det ad forskellige veje. Mens Sakajevs eksilregering vil en eller anden national suverænitetsstatus om nødvendigt gennem samarbejde med Rusland og ved hjælp af det internationale samfund, så ønsker bevægelsen Frit Kaukasus total uafhængighed for hele regionen, om nødvendigt gennem fortsat kamp. Frihed fra Rusland er øverste bud.

Som Iljas Musajev udtrykker det, har russerne splittet tjetjenerne, de har faktisk vundet ved at så splid, således at den ene gruppe, der fortsat slås for frihed, måtte gå i landflygtig- hed, mens den anden søger konsensus med Rusland. For øvrigt kommer uenighederne også til udtryk gennem navngivningen: Kadyrovs Tjetjenien kaldes på russisk 'Tjetjnja', den kaukasiske bevægelse kalder gerne landet på tyrkisk for 'Tjetjenia', mens eksilregeringen bruger det gamle navn 'Itjkeria'.

Det er spændende at være med i denne proces. Deltagerne er meget engagerede og lyttende. Og de lægger vægt på, at jeg er med, og behandler mig med respekt. Men det udnyttes også, at jeg deltager. Jeg citeres ofte for noget, som jeg ikke har gjort eller sagt. For eksempel bruges mit navn og min underskrift en gang imellem som garant for en mening, uden at jeg har givet mit tilsagn. Jeg behandles som et medlem til trods for, at jeg er observatør. Jeg tager dette som bevis på, at der er meget at lære om demokrati for eksilorganisationen. Men det er givende, at moderate og sekulære eksilorganisationer tilbyder løsninger, som er anderledes end de radikale løsninger i selve Tjetjenien.

Det er for tidligt at sige, om nogen af organisationerne får momentum, men der er lang tradition for eksilets betydning for udviklingen i udemokratiske lande.

Helen Krag er forsker med speciale $i \mathrm{Kau}$ kasus-regionen ved Institut for Minoritetsstudier Københavns Universitet. 